\title{
PARTIDOS POLÍTICOS E GÊNERO: MEDIAÇÕES NAS ROTAS DE INGRESSO DAS MULHERES NAREPRESENTAÇÃO POLÍTICA
}

\author{
Clara Araújo
}

\section{RESUMO}

O artigo discute a relação entre as chances de acesso das mulheres à representação política, particularmente à representação legislativa, e as formas de sua inserção nos partidos políticos. No primeiro momento, os tipos de representação e o sistema partidário são enfocados como dimensões do sistema político e eleitoral. Em seguida o sistema partidário é mais bem analisado em seus aspectos organizacionais e ideológicos. Com base na análise da literatura que aborda o tema, procura-se refletir sobre alguns condicionantes institucionais desses sistemas que interferem de maneira positiva ou negativa nas chances de as mulheres disputarem e se elegerem pelos partidos. No segundo momento, as experiências recentes de adoção de cotas por sexo para candidaturas proporcionais são inseridas na análise. A partir de pesquisa sobre o caso brasileiro, procura-se observar como as características do sistema partidário e os condicionantes discutidos podem afetar os resultados das cotas. As conclusões destacam que o acesso das mulheres à representação política é condicionado por um conjunto de fatores que ultrapassam a engenharia do sistema político, mas que tal engenharia tem um peso e pode favorecer mais ou menos o ingresso feminino na política. Como a pesquisa sugere, essa influência pode operar, também, sobre a possibilidade de que as cotas sejam assumidas de maneira mais burocrática ou mais efetiva pelos partidos brasileiros.

PALAVRAS-CHAVE: gêneros; partidos políticos; engenharia institucional; cotas de gênero.

\section{INTRODUÇÃO}

O acesso das mulheres à representação política e, particularmente, aos espaços legislativos vem sendo objeto de inúmeros estudos acadêmicos a partir do início da década de 1990. Três aspectos articulados parecem ter contribuído particularmente para isso: a) a legitimidade que o feminismo como movimento e suas demandas adquiriram nas últimas décadas; b) como conseqüência, o contraste entre o grau de conquistas ou de participação das mulheres em esferas da vida social, como na educação e no trabalho, e a sua pequena inserção nas instâncias decisórias do poder ${ }^{1}$ e c) a disseminação de novas estratégias, voltadas para romper esse quadro, particularmente as experiências

\footnotetext{
1 Alguns dados são ilustrativos desse cenário: em 2000, entre 193 países no mundo, apenas nove tinham mulheres como governantes/presidentes eleitas; apenas 39 países já tiveram mulheres eleitas para a Presidente ou PrimeiraMinistra e, de acordo com estimativas da Organização das Nações Unidas, as mulheres representavam menos de 1/10 dos gabinetes ministeriais no mundo (NORRIS, 1999).
}

de cotas para a competição legislativa. Nas investigações sobre as razões dessa tímida representação, bem como sobre a viabilidade dessas novas estratégias, o papel e o lugar ocupado pelos partidos políticos, veículos tradicionais de acesso aos cargos eletivos, tornam-se objeto de atenção particular.

A análise do tema requer que o consideremos sob o prima dos múltiplos fatores que constituem aspectos de mediação e que ajudam a definir os padrões de gênero que conformam o acesso à representação política. Em outros termos, para compreendermos o que ocorre com a participação das mulheres nos partidos e nas rotas de ingresso aos cargos eletivos de representação política, faz-se necessário considerar, simultaneamente, sua dimensão histórica, ou seja, a exclusão das mulheres no advento da condição de cidadãs e da ordem política moderna; as manifestações culturais - atitudes e práticas preconceituosas ou explicitamente discriminatórias que envolvem as relações de gênero em geral e que se reproduzem, também, no interior dos partidos políticos -; as características sócio-econômicas mais gerais dos 
países, assim como as dimensões institucionais do sistema político, incluindo-se as características do sistema partidário (ver, por exemplo, CHAPMAN, 1993; NORRIS, 1993; 1996; NORRIS \& LOVENDUSKI, 1995; IPU, 2000; NORRIS \& INGLEHART, 2000; 2003; VIEGAS \& FARIAS, 2001). Em outros trabalhos essa perspectiva foi oportunamente abordada para pensar o caso brasileiro (ARAÚJO, 1999; 2001).

O presente artigo tem por objetivo discutir a intercessão entre gênero e partidos políticos no acesso das mulheres à representação política. Trata, de modo mais específico, de um aspecto institucional, o sistema partidário, em sua relação com o sistema eleitoral e em seu desenho organizacional, procurando destacar pontos de mediação entre essas características e os padrões de inserção por gênero. A primeira parte apresenta uma síntese dos principais fatores institucionais destacados pela literatura internacional. A segunda procura identificar aspectos relacionados com o sistema partidário brasileiro para, em seguida, destacar algumas características e práticas relacionadas com a inserção das mulheres nos partidos. Além da análise da literatura, a segunda parte está baseada, também, em pesquisa que vem sendo desenvolvida desde 1997, visando a acompanhar o processo de implantação das cotas no país, envolvendo alguns dos principais partidos políticos e os resultados eleitorais ${ }^{2}$.

\section{O SISTEMA POLÍTICO INSTITUCIONAL E O LUGAR DOS PARTIDOS}

O sistema partidário é um dos componentes do sistema político atual, genericamente identificado como "democracia representativa ocidental". Nesse sistema, em que o voto constitui a forma de escolher e legitimar a representação política e

\footnotetext{
2 A pesquisa vem acompanhando os processos eleitorais de 1996, 1998, 2000, 2002 e 2004, envolvendo um estudo mais sistemático sobre seis partidos políticos (Partido do Movimento Democrático Brasileiro (PMDB), Partido dos Trabalhadores (PT), Partido Democrático Trabalhista (PDT), Partido da Frente Liberal (PFL), Partido Progressista Brasileiro (PPB) e Partido da Social-democracia Brasileira (PSDB)). Foram feitas entrevistas com dirigentes partidários, parlamentares e candidatos não-eleitos, de ambos os sexos, cobrindo os pleitos entre 1996 e 2002, perfazendo 92 entrevistas. Para os resultados eleitorais quantitativos todos os partidos políticos vêm sendo considerados.
}

os partidos o canal que a viabiliza, a relação entre sistema partidário e sistema eleitoral é intrínseca e a compreensão da organização e das práticas partidárias necessita ser pensada, em última instância, em relação ao sistema eleitoral. Obviamente, o sistema partidário é mais amplo do que a representação partidária, de modo que o primeiro não se restringe à sua representação política eleita, constituindo-se em um dos vários canais de organização coletiva e de veiculação de idéias em relação à vida social e política. A política, na sua forma institucionalizada, é organizada e legitimada por meio de uma estrutura que tem na eleição de governantes e parlamentares, em geral por meio de partidos, o seu principal mecanismo legitimador. O poder político representativo é requisito e dado constitutivo da vida social moderna, e os partidos são organizados com vistas à disputa desse poder. Suas ações e políticas são orientadas, em última instância, pela busca de acesso ao poder, cujo canal de exercício e de disputa política é a representação parlamentar e/ou governamental. Assim, ao lado de posições ideológicas, são os cálculos eleitorais que influenciam na esfera organizacional, definem as estratégias partidárias e o lugar dos atores nessas estratégias, inclusive o recrutamento e os investimentos eleitorais.

O sistema partidário, embora analiticamente visto como um componente institucional próprio, existe em relação com, influencia e é influenciado pelo sistema eleitoral. Isso significa considerar, também, que muito das estratégias dos partidos e a própria formatação do sistema partidário - maior ou menor fragmentação ou perenidade, entre outros -, não decorre exclusivamente das práticas dessas organizações. Ao contrário, os partidos são influenciados tanto pela cultura política mais geral como pelas características do sistema eleitoral.

Os partidos não são instituições fixas e imutáveis, ao contrário, estão em constante fluxo, adequando-se aos imperativos do contexto político a que se vinculam. Nesse sentido, também refletem as características mais amplas de cada sociedade. Mas a literatura tem apontado para certos elementos recorrentes que afetam os partidos em geral, permitindo estabelecer padrões e tendências no interior de um determinado sistema político (KATZ \& MAIR, 1992). Considerando o que foi dito acima, quanto à razão de ser dos partidos em geral, podemos analisá-los em dois níveis: a) no nível intrapartido, em relação à organização e a 
ideologia e b) no nível da competição eleitoral, na relação entre partidos. Como as mulheres posicionam-se e têm sido posicionadas frente a essas duas dimensões?

Podemos pensar a inserção das mulheres nos partidos e seu acesso à representação política a partir desses níveis, considerando sua inserção organizacional, o processo de recrutamento legislativo, que inclui fases distintas, e o comportamento partidário diante das regras do sistema eleitoral. Em suma, o sistema partidário em geral e o contexto específico dos partidos políticos em particular constituem variáveis que ajudam a entender não apenas a dinâmica da participação partidária mas, sobretudo, os padrões de inserção das mulheres nas instâncias legislativas.

III. RELAÇÃO ENTRE SISTEMAS POLÍTICOS DE REPRESENTAÇÃO E ELEGIBILIDADE DAS MULHERES

Considerando o sistema partidário em sua relação com o sistema eleitoral de cada país e o sistema de representação mais geral, há evidências de que os sistemas proporcionais são mais favoráveis às mulheres, seguidos dos sistemas mistos $^{3}$ e, por último, dos sistemas majoritários (ZIMMERMAN \& RULE, 1994; RULE, 1997; MATLAND, 2002; NORRIS, 2003; NORRIS \& INGLEHART, 2003). É importante salientar que tais constatações não estabelecem uma relação automática de causa e efeito. Outros fatores influenciam e condicionam a participação das mulheres e, em certas circunstâncias, tornam-se mesmo preponderantes sobre aspectos do sistema eleitoral. Mas embora essa seja a tendência geral, importa observar que quando outras variáveis são inseridas, tais como nível de desenvolvimento sócio-econômico e valores culturais, mais igualitários ou mais hierárquicos, ou ainda a influência da religião sobre a vida social, tais correlações tendem a sofrer alterações. Os valores culturais surgem como particularmente relevantes (NORRIS \& INGLEHART, 2003).

Em linhas gerais, destacam-se algumas razões pelas quais os sistemas proporcionais seriam mais

\footnotetext{
3 É o que definimos como distrital misto. Sobre esses sistemas, estudos indicam, também, que as mulheres tendem a obter melhores desempenhos nos processos proporcionais e obtêm resultados fracos na parcela majoritária da eleição (RULE \& ZIMMERMAN, 1994; NORRIS, 2003).
}

benéficos às mulheres. Em primeiro lugar, nos sistemas proporcionais, cada partido apresenta ao eleitorado sua lista coletiva de candidatos para cada distrito. Como, em geral, tais listas comportam vários nomes, o partido tende a ter um incentivo eleitoral para maximizar esse apelo coletivo, incluindo candidatos representando as diversas configurações sociais. A não-inclusão de pessoas oriundas de grupos sociais considerados relevantes socialmente e com apelo eleitoral, como são as mulheres atualmente, poderia ser vista como discriminatória. Já em sistemas majoritários, cada partido seleciona um único candidato por distrito. Nesses casos, tem sido observado que os selecionadores tendem a escolher candidatos que maximizem as chances e minimizem os riscos eleitorais, independentemente da configuração final da representação nacional. E quem são esses candidatos? Esse é o segundo aspecto: cada tipo de sistema eleitoral está também relacionado a padrões de eleição e de reeleição de candidatos. Independentemente das regras internas e das características organizacionais dos partidos, que serão abordadas mais adiante, um aspecto extensivo aos partidos em todos os sistemas é a corrida pela obtenção do maior número de votos possível. Nesse sentido, as escolhas preferenciais dos partidos serão feitas com base na análise dos candidatos considerados "bons de voto" e também daqueles considerados "ruins de voto". Nesse processo, tende-se a desenvolver-se uma lógica que é, ao mesmo tempo, pragmática e inercial, que se reproduz de modo mais intenso nos sistemas majoritários. Supõe-se que candidatos que já são parlamentares ou que tiveram votações expressivas em pleitos anteriores tendem a oferecer menor risco na competição, pois teriam base eleitoral, nome conhecido e estrutura criada pelo próprio mandato. Assim, parcela significativa das vagas ou da prioridade eleitoral ${ }^{4}$ tende a ser direcionada para aqueles que já estão ocupando cargos e estão tentando reeleição ou então que disputam pela primeira vez mas compõem o perfil tradicional do representante partidário.

Existem certas características que os

\footnotetext{
4 No caso brasileiro, cujo universo de vagas é bastante amplo em razão das alterações que definiram em 150\% das cadeiras em disputa o número de candidatos que pode ser lançado, essa análise pode ser trazida para a definição das prioridades e investimentos partidários.
} 
selecionadores (dirigentes partidários) buscam nos candidatos, normalmente identificados com os padrões dos eleitos pelo partido, além da trajetória do candidato no partido e na área/distrito pela qual se candidata. E, por motivos históricos, aqueles que já estão eleitos, estão ocupando cargos ou têm históricos partidários são, predominantemente, homens. Nesse cenário, o fato de o sistema ser proporcional abre mais espaço para que os partidos busquem incluir em suas listas os diferentes perfis sociais, pois isso também se traduz em soma de votos para a legenda e permite incluir novos perfis que emergem como relevantes ${ }^{5}$. Tem sido observado que o problema das mulheres não reside tanto em conseguir serem indicadas candidatas e, sim, em conseguirem condições efetivas de competir no primeiro momento, internamente nos partidos, com aqueles que já detêm certa vantagem eleitoral como a de possuir mandato ou ter redes partidárias de apoio e, em seguida, externamente ao partido, no mercado eleitoral (NORRIS, 2003). Nos sistemas majoritários, tal tarefa torna-se mais árdua, pois implica conseguir vagas do partido em distritos potencialmente elegíveis. Nos sistemas proporcionais de lista fechada, o desafio consiste em ocupar um lugar no topo dos preferenciais da lista de candidatura; nos proporcionais de lista aberta, em obter certas prioridades nos recursos destinados aos preferenciais. Dois exemplos são citados para ilustrar essa situação: a) o dos Estados Unidos, onde se constatou que o índice de reeleição entre o final da década de 1970 e o meio da década de 1990 situou-se em 85\% dos representantes, e b) o Reino Unido entre as eleições de 1997 e 2001. Neste último caso, em razão da adoção de políticas de cotas no Partido Trabalhista e de sua grande vitória sobre o "tatcherismo", em 1987 as mulheres saltaram de uma representação de 6\% na Câmara dos Comuns para pouco mais de 18\%. Apesar de a política de cotas ter sido abolida posteriormente, as parlamentares que concorreram conseguiram reeleger-se em 2001.

A maximização do cálculo eleitoral passa, portanto, pela preservação de um potencial de elegibi-

\footnotetext{
5 Nesse sentido, uma das explicações da relativa facilidade para a aprovação das cotas no país é que ela, além de não alterar a engenharia eleitoral, pois não retira ninguém e tampouco estabelece qualquer punição para o não-preenchimento, também implica algum ganho, pois todos os votos que entram, mesmo aquelas poucas dezenas, somar-seão ao quociente eleitoral.
}

lidade por parte dos que já detêm mandatos. Para as mulheres que estão ingressando, ao desafio de competir com os detentores de mandatos soma-se a necessidade de conseguirem ser incluídas nos critérios anteriormente mencionados, relacionados com uma trajetória partidária e/ou política externa ao partido, seja como liderança associativa, seja representante de cargo público, entre outros. E aqui, também, as mulheres podem encontrar-se em desvantagem. Como observou Matland (2002, p. 113), o fato de esses lugares tradicionalmente serem ocupados por homens tende a gerar padrões de eleição e perfis com potenciais eleitorais também associados aos padrões masculinos. Essa característica aqui denominada de "inércia” e de "maximização" recorta todos os sistemas, mas tende a estar mais presente nos sistemas majoritários, porque o filtro dos elegíveis é mais estreito, há poucos e grandes partidos competindo e eles tendem a possuir seus perfis eleitorais tradicionais e enraizados, deixando pequena margem de manobra para o ingresso de setores historicamente excluídos.

O sistema proporcional tende ainda a ser considerado mais vantajoso porque favorece o "efeito-contágio”, isto é, o efeito gerado por determinada iniciativa de um partido, que, quando positiva, tende a ser incorporada por outros partidos em razão de seu apelo eleitoral. Esse movimento tende a ser mais dificultado quando existem poucos partidos com perfis de elegibilidade mais consolidados. Por fim, o sistema proporcional vem sendo considerado favorável porque torna mais viável a adoção de estratégias de ação afirmativa tais como as cotas, uma vez que sempre há uma pluralidade mínima de candidatos concorrendo. Já entre os sistemas majoritários, torna-se mais difícil conseguir comprometer partidos com metas de indicação de mulheres (SCHMIDT, 2003).

Quanto aos sistemas mistos, tem sido constatado que, internamente a esses sistemas, proporcionalmente mais mulheres têm sido eleitas por meio das listas partidárias do que por meio dos distritos majoritários ou uninominais. Essa relação entre sistema eleitoral e elegibilidade das mulheres levou autores a designar os sistemas proporcionais como friendly-system ${ }^{6}$ em relação às mulheres (RULE \& ZIMMERMAN, 1994; MATLAND, 2002; NORRIS, 2003). Segundo cálculos de Norris (2003, p. 1), o percentual mé-

\footnotetext{
6 “Sistema amigável” (nota do revisor).
} 
dio de mulheres parlamentares nos sistemas majoritários ficava em 8,5\%, nos sistemas mistos em $11,3 \%$ e, nos proporcionais, em $15,4 \%$, indicando que as mulheres têm duas vezes mais chances de serem eleitas nos sistemas proporcionais do que nos majoritários. Poucos são os sistemas mistos que adotam cotas, mas estudos que começam a ser feitos sobre a relação entre efeito de cotas e sistemas eleitorais têm mostrado que entre os que adotam as cotas para ambos os tipos de eleição - proporcional e majoritária - os resultados tendem a ser mais efetivos na parte proporcional do processo. Contudo, importa considerar que, além de outros fatores influenciarem as chances de eleição, no interior do sistema proporcional há também distinções no sistema eleitoral, tais como a magnitude dos distritos, o cálculo da distribuição das cadeiras e o tipo de lista eleitoral. Há autores que distinguem ainda o sistema eleitoral do que é definido como as "normas de distribuição da proporcionalidade”. Tavares (2002, p. 9), por exemplo, sugere que, em se tratando de análises sobre representação legislativa em sistemas proporcionais em que o número de representantes eleitos por distritos é diferente, é necessário "[...] distinguir, na totalidade do sistema representativo, dois conjuntos, fundamentais e independentes entre si, de normas reguladoras: o apportionment, isto é, os critérios e o processo de distribuição das cadeiras parlamentares entre os diferentes distritos, e o sistema eleitoral, isto é, as regras e os mecanismos que, formalizados em normas legais, regulam a conversão, no interior de cada distrito eleitoral, dos votos partidários em assentos legislativos partidários [...]. Essa distinção é particularmente importante para identificar com clareza e precisão as distorções fundamentais do sistema representativo na federação brasileira, que decorrem do apportionment e apenas secundariamente do sistema eleitoral propriamente dito, isto é, da representação proporcional”.

Todos esses aspectos, que não serão objeto de análise no presente texto, podem influenciar de modo diferenciado as chances eleitorais das mulheres. Apenas a título de exemplo, vale registrar que a literatura em geral considera que a magnitude do distrito pesa e nos distritos considerados grandes, isto é, com maior número de cadeiras, a eleição das mulheres tende a ser menos difícil'.

${ }^{7}$ Embora essa seja a tendência geral, não parece ser o caso

\section{RELAÇÃO ENTRE SISTEMAS PARTIDÁRI- OS E ELEGIBILIDADE DAS MULHERES}

Como a seção anterior procurou demonstrar, em relação aos tipos mais gerais de sistemas políticos de representação as evidências tendem a ser mais claras. Contudo, o mesmo não parece ocorrer em relação ao sistema partidário stricto sensu. Não há propriamente um consenso ou mesmo um conjunto mais sistemático de evidências empíricas que indiquem padrões claros acerca de como a natureza do sistema partidário afetaria a eleição das mulheres. Mas seguindo o raciocínio apresentado no início deste texto, tem sido sugerido que os sistemas pluripartidários característicos da representação proporcional, isto é, sistemas que não contam apenas com dois ou três grandes partidos na representação tendem a apresentar proporção mais elevada de mulheres eleitas (DARCY, WELCH \& CLARCK, 1994; RULE \& ZIMMERMAN, 1994; IPU, 1997; DIAZ, 2002; HTUN, 2002; MATLAND, 2002; SCHMIDT, 2003). As razões seriam o fato de tais sistemas possuírem mais partidos competindo e de o pluripartidarismo estimular o "mercado eleitoral" e possibilitar o surgimento mais constante de novos partidos, que tendem a absorver novos atores sociais. Ao contrário, os sistemas dominados por poucos e grandes partidos tendem a reduzir as oportunidades para os setores que tradicionalmente se encontram fora dos centros decisórios da política, porque suas bases de apoio já se encontram padronizadas e consolidadas e sua tendência é reproduzir os padrões de recrutamento já estabelecidos.

Assim, a competição partidária mais diversificada, combinada com o surgimento de novos partidos, tende a proporcionar mais oportunidades de ingresso para as mulheres na esfera política. Nessa perspectiva, a fragmentação partidária ${ }^{8}$ não é entendida como necessariamente

no Brasil; alguns autores sugerem que, em algumas circunstâncias, distritos menores podem vir a ser mais favoráveis (SCHMIDT, 2003).

8 Esse conceito refere-se ao universo de partidos existentes. O grau de fragmentação é mensurado a partir de fórmulas específicas. Em análise comparada internacional, os grandes partidos são definidos como aqueles que detêm mais de $30 \%$ das cadeiras do parlamento (IPU, 1997). Tais análises consideram sistemas eleitorais diversos, incluindo proporcionais, mistos e majoritários; os últimos tendem a ter poucas siglas partidárias representadas no parlamento. No caso 
danosa ou constrangedora para o processo de incorporação de mulheres. Na interpretação de alguns autores, essa fragmentação tende mesmo a ser interpretada como benéfica, pois, ao estimular a competição, estimularia a incorporação dos novos atores (SAINSBURY, 1993). Contudo, há divergências quanto ao impacto dessa fragmentação sobre o sistema político, ou seja, se a partir de determinada intensidade - isto é, um número muito grande de partidos - ela já se tornaria problemática e nociva ao funcionamento do sistema de representação e, em conseqüência, ao acesso das mulheres. Há defensores do sistema proporcional que argumentam que tanto a concentração partidária que restringe a competição a poucos e, em geral, tradicionais partidos, como a excessiva fragmentação, que permite a existência de um grande número de partidos regionalizados e a eleição de parlamentares com menos de $1 \%$ dos votos válidos, são manifestações problemáticas à expressão e incorporação de novas parcelas de atores sociais (TAVARES, 2002).

Observações nessa mesma perspectiva são feitas em relação às possibilidades de incorporação das mulheres aos processos de competição eleitoral. A representação proporcional beneficia mais as mulheres porque permite a existência de um número maior de partidos e mesmo o surgimento de agremiações novas e não-tradicionais - portanto, mais abertas aos outsiders ${ }^{9}$. No entanto, quando essa representação é marcada pela proliferação e pela constante dissolução de partidos, tende a tornar-se adversa. Um estudo comparado envolvendo diversos países europeus (IPU,

brasileiro, mesmo após a redemocratização e até 1986 houve partidos com mais de 30\% de cadeiras. Mas a ampliação do quadro partidário e as mudanças na correlação de forças provocaram alterações, de tal modo que, a partir de 1990 , os maiores partidos situaram-se entre 20 e $25 \%$ de cadeiras eleitas. Nas eleições de 1994 e de 1998 dezoito partidos conseguiram eleger representantes. Nas últimas eleições, dezenove partidos, de um total de 30, elegeram representantes para a Câmara, mas o partido que mais elegeu, o PT, ficou com 17,74\% das cadeiras. Algumas classificações propostas (RODRIGUES, 1995) para a situação brasileira consideravam partidos grandes aqueles com mais de 81 cadeiras na Câmara dos Deputados; partidos médios entre 30 e 80 , partidos pequenos entre dez e 30 e nanicos, abaixo de dez. Contudo, a distribuição atual da representação tornou obsoleta essa classificação.

9 “Aqueles que estão fora” (N. R.).
1997) ${ }^{10}$ concluiu que havia dois padrões de elegibilidade partidária em relação às mulheres. O primeiro era referido ao perfil ideológico, com os partidos mais à esquerda elegendo mais do que os de centro e, sobretudo, os de direita; o segundo, em relação à magnitude do partido: os partidos de médio porte tenderiam a eleger mais mulheres e elas teriam menos chances nos extremos, isto é, em partidos muito grandes e nos muito pequenos. Nesse cenário, o surgimento de novos partidos seria favorável somente se se tratassem de agremiações progressistas, porque trariam incorporado um compromisso de princípio. Partidos tradicionalistas, sobretudo os de corte religioso, não contariam muito, pois não incorporam muitas mulheres e não dão relevância a essa questão (CHAPMAN, 1993; DIAZ, 2002).

A magnitude dos partidos e o grau de fragmentação partidária gerado pelas diferenças entre os diversos sistemas eleitorais são fatores que podem propiciar maior ou menor chance de eleição para as mulheres. Quanto menos pluripartidário é o sistema, mais ele caracteriza-se por partidos muito grandes e mais consolidados, os quais não se encontrariam suficientemente abertos ao ingresso de novos atores. Ademais, o custo eleitoral da competição entre candidatos em seu interior tende a ser muito elevado. Por outro lado, partidos muito pequenos e regionalizados, que disputam para eleger um ou dois candidatos, tendem a dar prioridade eleitoral aos seus dirigentes, em geral homens.

A situação brasileira pode ser ilustrativa dessa análise. Se observarmos o cenário das candidaturas, notamos que os partidos denominados de “nanicos” tendem a apresentar elevado percentual de candidatas quando comparados aos partidos maiores. Contudo, a elegibilidade das mulheres é muito pequena, não obstante elas somarem votos para que alguns candidatos possam eleger-se. Nas eleições de 2002, apenas duas, das 42 parlamentares federais, foram eleitas por partidos muito pequenos.

Como foi assinalado, o processo de recrutamento eleitoral é mediado por fatores internos e

10 Note-se que, embora em uma perspectiva comparada, o estudo toma critérios de sistemas eleitorais europeus, incluindo sistemas majoritários, para definir partidos grandes como aqueles com mais de $30 \%$ de representantes. A análise, portanto, não é generalizável. 
externos ao partido e ao próprio sistema eleitoral. A eleição das mulheres também é mediada por um processo que envolve desde as motivações individuais para candidatar-se -condicionadas por sua disposição, pelas oportunidades para disputar e pela análise dos recursos disponíveis - até a possibilidade de ser indicada pelo partido. Isso, na maioria dos casos, implica um cálculo pragmático da correlação de forças e dos objetivos partidários em uma determinada eleição, passando, ainda, por seus compromissos ideológicos.

Até aqui foram abordados os aspectos mais gerais do sistema eleitoral em sua relação com os partidos, ou o que poderíamos definir como fatores externos. A seguir, a análise dirigir-se-á às dimensões internas aos partidos.

\section{CONTEXTOS PARTIDÁRIOS, PERFIS IDE- OLÓGICOS E ORGANIZACIONAIS E O ACESSO DAS MULHERES}

O contexto partidário, os efeitos internos aos partidos políticos, no que tange, sobretudo, à sua ideologia e à sua organização, são aspectos que, relacionados às características mais gerais da competição partidária, exercem influência sobre o recrutamento e sobre as chances eleitorais das mulheres (LOVENDUSKI, 1993; 1995; ERICKSON, 1993; NORRIS, 1996, 2003; IPU, 2000; MATLAND, 2002).

\section{V.1. A dimensão ideológica}

No que diz respeito à dimensão ideológica, a literatura indica que o engajamento político das mulheres tem sido bem mais estimulado e, de certa forma, condicionado, pelos partidos de esquerda. O amplo estudo comparativo de Katz e Mair (1992), envolvendo 30 anos (1960-1990) de existência de organização de 79 partidos de democracias consideradas consolidadas, mostra que foram os partidos de esquerda os primeiros a incluir algum tipo de norma interna voltada para ampliar a participação das mulheres. Talvez seja por isso que, desde os primeiros anos analisados, esses partidos detivessem percentuais maiores de dirigentes e de representantes parlamentares. Todos os estudos mais recentes corroboram essa tendência.

Entretanto, sobretudo a partir da última década, ocorreu uma disseminação de iniciativas e da inclusão do tema nas agendas de partidos de outros espectros ideológicos. Ao implementarem políticas de gênero e lançarem mais candidatas a cargos legislativos, os partidos de esquerda terminaram desencadeando o mencionado "efeito contágio” sobre as outras organizações, inclusive as de corte mais conservador. Importa notar que, nesse processo, há um movimento de mão-dupla. Por um lado, a crescente organização das mulheres tende a exercer pressão no sentido de que suas demandas sejam apoiadas pelas direções partidárias. Por outro, a descoberta de que as mulheres são uma força eleitoral decisiva e, portanto, suas demandas não podem ser desprezadas, conduz os partidos a assumir algum nível de compromisso público em relação ao problema da sua inserção nas esferas de poder.

As derrotas eleitorais também podem operar como elemento de estímulo a mudanças nas políticas partidárias, quando os partidos vêem-se obrigados a reavaliar o peso do eleitorado feminino e assumir um discurso mais aberto à causa feminista. Essa foi a situação vivida, por exemplo, pelo Partido Trabalhista na Inglaterra em 1997 e por alguns partidos noruegueses (SKJEIE, 1996). Esse efeito não necessariamente se reflete em níveis de compromissos idênticos entre as diversas organizações partidárias mas, de todo modo, obriga-as a assumir algum tipo de manifestação pública, formal ou efetiva. Até o final da década de 1990 constatava-se que, mesmo entre os partidos mais comprometidos com a incorporação das mulheres, as estratégias mais radicais eram aquelas voltadas para trazer mulheres para posições internas; quando se tratava de nomeá-las como candidatas, sobretudo ao parlamento nacional, as estratégias tornavam-se menos radicais e mais diluídas. Com base na análise das tentativas de resposta dos partidos às demandas feministas, diante do peso crescente do eleitorado feminino, Lovenduski (1996), em levantamento envolvendo as iniciativas de partidos de diferentes países, identificou três tipos básicos de estratégias que têm marcado os partidos políticos em suas respostas às demandas das mulheres, correspondendo a níveis distintos de compromisso. Posteriormente, Norris (2003) aprimorou essa tipologia, alterando algumas de suas designações e detalhando as características de cada estratégia, ampliando-as para pensar políticas que extrapolam iniciativas dos partidos. Em linhas gerais, essas estratégias são:

a) estratégia da retórica: envolveria assinaturas de acordos internacionais no plano governamental e, entre os partidos, implicam que as questões das mulheres são aceitas em plata- 
formas de campanhas e assumidas em discursos, mas não existem políticas efetivas sendo implementadas. Exemplos de estratégias de retórica seriam a assinatura de compromissos derivados de convenções internacionais sobre direitos das mulheres. Dependendo do compromisso das lideranças e do poder no interior dos partidos, as mulheres podem ser apontadas para a disputa ou a ocupação de alguns cargos. Norris (idem) observa que esses ganhos, em geral, não são institucionalizados, mas derivados de líderes individuais e que podem ser desfeitos em qualquer alteração de contexto. Alerta ainda para o risco de mulheres indicadas por esses processos terem seus mandatos ou cargos vistos como concessões e não resultados de bases eleitorais ou partidárias próprias;

b) estratégias de políticas de ação afirmativa (Lovenduski) ou de igualdade de oportunidades (Norris): visam a propiciar às mulheres certas condições de modo a que possam desenvolver suas carreiras políticas com as mesmas condições dos homens. São definidas por certos compromissos que vão além dos assumidos nas plataformas eleitorais ou em assinaturas formais de tratados pelo poder público; entre estes, podem ser citados os seminários, treinamentos e metas de inclusão a serem alcançadas pelo partido; treinamento de técnicas, programas financeiros e ajuda para que as mulheres possam enfrentar as campanhas eleitorais ou, ainda, como política institucional, apoios como creches e facilidades para que as mulheres possam exercer e participar das atividades políticas e

c) estratégias de discriminação positiva: elaboradas de maneira específica para beneficiar as mulheres durante um determinado período de tempo. Nessas estratégias, há uma intervenção mais incisiva caracterizada especialmente pela adoção de sistemas de cotas para as instâncias decisórias e para a representação pública do partido, além de outras políticas de gênero, como o treinamento para as competições eleitorais.

Levantamentos recentes sobre iniciativas de nomeação de candidaturas indicam que esse quadro vem mudando um pouco e o último tipo tende a ser mais disseminado, sobretudo em razão das políticas de cotas, que passaram a ser a estratégia privilegiada (BALLINGTON \& MÉNDEZMONTALVO, 2002; HTUN \& JONES, 2002; NORRIS, 2003). Ainda assim, o parlamento nacional apresenta-se como locus central de dificuldade e resistência partidária no que concerne ao ingresso de mulheres na representação política.

A implantação dessas estratégias é condicionada pelo grau de participação e organização das mulheres no interior dos partidos, pelo perfil ideológico dos mesmos e também pelos contornos mais gerais do sistema político. Este último fator cria certos imperativos que os partidos necessitam responder e que determinam a capacidade de absorção das demandas feministas. As dificuldades de adoção de cotas em países de sistema majoritário, por exemplo, necessitam ser vistas sob esse prisma. A depender do sistema de representação, independentemente do perfil ideológico, a implantação das cotas pode ser praticamente impossível. No sistema majoritário, a adoção da cota implica observar a proporção de distritos que terá candidatos de um ou de outro sexo, o que pode interferir na lógica de maximização de votos que tende a comandar os partidos. Por outro lado, os sistemas proporcionais podem facilitar a adoção de tais políticas uma vez que comportam mais de um candidato por distrito.

Entretanto, como foi visto, o acesso das mulheres à representação política é influenciado por vários fatores, inclusive as leis eleitorais, entendendo-as como os sistemas eleitorais básicos, a adoção de medidas específicas como as cotas e outras formas de incentivos estratégicos para os selecionadores partidários e para os candidatos (NORRIS \& INGLEHART, 2003). Como sugerem esses autores, a lógica da preservação ou expansão dos ganhos eleitorais tende a exercer um efeito inercial nos partidos, lógica esta que pode ser quebrada pelas cotas, mas que também condiciona a possibilidade de sua implementação, mesmo quando há compromissos ideológicos mais explícitos.

Em alguns casos, as cotas podem assumir uma característica mais formal, a depender do tipo de sistema eleitoral, como parece ser o caso do Brasil. De outra parte, os estudos empíricos apontam para uma relação entre perfil ideológico partidário e tipo de estratégia mais adotada: os partidos mais conservadores tenderiam a assumir, principalmente, as chamadas "estratégias de retórica"; os de centro, as "estratégias de ação positiva”, e os de 
esquerda são os que mais assumem as "estratégias de discriminação positiva” (LOVENDUSKI, 1996). Essas duas correlações - por sistema de representação e por perfil ideológico - são bem exemplificadas em levantamento recente envolvendo os partidos dos países que compunham a comunidade européia até 2003 (NORRIS, 2003). Assim, com exceção da Bélgica, que tem sistema de cotas, e da França, que estabelece um princípio de paridade em sua constituição, em todos os outros países as cotas eram voluntárias, isto é, não existiam legislações que as regulassem ou tornassem-nas obrigatórias aos partidos ${ }^{11}$. No citado levantamento, foram analisados partidos considerados relevantes - com um mínimo de dez representantes nas Câmaras de Deputados no ano 2000 - perfazendo um total de 76 partidos. Entre estes, 35 tinham cotas para candidaturas, 34 não possuíam essa medida e os sete restantes não tinham informações disponíveis. Entre os 35 partidos que adotavam cotas, nove pertenciam a sistemas majoritários e 24 a sistemas proporcionais.

Importa lembrar que os sistemas proporcionais tendem a possuir um número maior de partidos. Mas isso também revela a maior facilidade de, nestes sistemas, medidas como cotas serem adotadas. Convém registrar, ainda, que tanto entre os partidos pertencentes aos sistemas proporcionais como entre aqueles inseridos nos sistemas majoritários, a maior parte dos que adotavam cotas era composta por um perfil ideológico de centro ou de centro-esquerda. Já em outro levantamento (IDEA, 2003), foram identificados 122 partidos em 58 países que adotam algum sistema de cotas para cargos legislativos em países que não possuem sistemas compulsórios de cotas. Mais uma vez, o levantamento permite constatar que o perfil ideológico é preponderantemente de esquerda ou centro-esquerda e que a adoção é maior nos sistemas proporcionais.

Em se tratando das ações relacionadas com a inserção das mulheres, ao lado da dimensão mais pragmática, envolvendo a sua capacidade de pressão e as expectativas eleitorais, as concepções ideológicas que orientam os partidos refletem-se também em suas ações, balizadas por suas concepções acerca das formas de exclusão social e

\footnotetext{
11 Outros países europeus, considerados democracias emergentes, adotaram cotas mais recentemente, como, por exemplo, a Macedônia.
}

política que atingem certos segmentos e grupos sociais. Em se tratando dos partidos de esquerda e/ou alternativos - como os partidos verdes -, como suas iniciativas em geral são orientadas pela necessidade de alterar esse cenário, ações que venham a interferir nesses processos tendem a ser bem-vistas. No que tange às estratégias de retórica dos partidos mais conservadores, elas envolveriam o reconhecimento de que é necessário incorporar mais mulheres, desde que a competição seja orientada pela premissa da igualdade de todos sem prejuízo de qualquer competidor. Nesse caso, é interessante mencionar uma observação de Norris (1993), para quem os argumentos que muitos partidos de direita ou de centro usam em relação a essas políticas de gênero assemelham-se aos utilizados para pensar a economia: baseiam-se em uma visão de livre mercado, no princípio de não-intervenção e na não-regulação do processo de recrutamento, concebendo o simples jogo da competição no "mercado eleitoral" como suficiente para equilibrar o cenário da disputa.

Mas a dimensão ideológica inclui, também, certa "cultura de gênero", expressa por meio de certos tipos característicos do eleitorado que os partidos procuram traduzir no perfil de candidatos selecionados para representá-los. Experiência ilustrativa dessa "cultura de gênero" é a do Partido Trabalhista inglês, tradicionalmente identificado como o partido da classe trabalhadora - classe, por sua vez, tradicionalmente identificada como masculina. Um dos problemas enfrentados pelas militantes do Partido Trabalhista durante muito tempo foi a dificuldade de convencer os dirigentes a sair das fronteiras do perfil tradicional do candidato - trabalhador do sexo masculino. Só foi possível abrir mais espaço para outros perfis políticos, particularmente para as mulheres, quando pesquisa conduzida com o intuito de explicar as derrotas eleitorais sofridas pelo Partido entre o final dos anos 1980 e o início dos 1990 mostrou que o eleitorado feminino não votou no Partido porque o identificava com um perfil muito específico e definido (SHORT, 1996).

Embora os três tipos de estratégias elaboradas por Norris e Lovenduski sejam, no essencial, aplicáveis aos partidos em geral, convém fazer algumas ponderações. Uma primeira é que as estratégias não podem ser vistas como rígidas ou contrapostas entre si. Em muitos casos, é possível encontrar iniciativas que mesclam as ações defi- 
nidas para uma ou outra estratégia, sobretudo em se tratando das estratégias de igualdade de oportunidade e de ação positiva. Uma segunda ponderação é quanto à definição hierárquica dessas políticas. A forma como elas são ordenadas sugere uma hierarquia de compromissos que vai de atitudes meramente retóricas a atitudes positivas intervencionistas, voltadas para um determinado grupo, as mulheres. Essa hierarquia tende a ser adequada à maior parte dos sistemas partidários europeus ou aos países com democracias mais consolidadas, nos quais o desenho do sistema partidário tende a ser mais consolidado, mas não é possível incorporá-la como um modelo que se encaixa em todo e qualquer contexto. No caso do Brasil e no de outros países com sistema de lista aberta, pode ser limitado definir como iniciativa máxima a existência de uma cota de candidaturas, pois, até o momento, isso diz muito pouco sobre os compromissos dos partidos com a eleição. Ademais, foi assinalado anteriormente que em muitas situações o importante não é tanto a obtenção de uma vaga para concorrer, mas a posição em que se concorre e o capital político de que se dispõe para fazê-lo. Pensando no caso do Brasil e na experiência de cotas, convém perguntar se as estratégias de "igualdade de oportunidade" ou de "ação afirmativa", tais como são definidas a partir de suas iniciativas, não poderiam ser tão eficazes quanto a estratégia de ação positiva. Isso porque, conforme será observado adiante, no atual sistema de votação, a adoção de cotas não tem implicado alteração no recrutamento, no perfil tradicional de elegíveis e tampouco em investimentos nas candidaturas femininas. De outro modo, vários estudos têm destacado que, no primeiro momento, a construção de bases eleitorais que permitam às mulheres candidatarem-se constitui o principal obstáculo e, em um segundo momento, o obstáculo para torná-las elegíveis é a construção de uma estrutura de campanha que, salvo exceções, depende também dos partidos.

\section{V.2. A dimensão organizacional}

A outra dimensão que afeta cada partido de maneira específica é a dimensão organizacional ${ }^{12}$. O grau e o tipo de organização interna de cada

\footnotetext{
12 À parte o consenso de que os partidos políticos perseguem o poder político, há diferentes formas de conceber a forma como isso é feito; ou seja, se o aspecto central da atuação partidária deve ser a ação eleitoral, a competição
}

partido são vistos como fundamentais para facilitar a inserção das mulheres e criar condições de competição. O nível de institucionalização organizacional do partido, seu ambiente interno, a perenidade e a homogeneidade de suas práticas são elementos que afetam a inserção das mulheres e dos outros setores que tradicionalmente não compõem os núcleos decisórios. Há uma grande variação nas características organizacionais mas, também aqui, é possível encontrar certa homogeneidade em torno de determinados padrões organizacionais. Em geral conclui-se que dimensões organizacionais mais estruturadas em regras transparentes e mais padronizadas tendem a ser mais democráticas porque permitem maior controle dos seus membros e condições prévias de participação àqueles que eventualmente queiram disputar um cargo. Nesse sentido, também o uso de determinada estratégia para ampliar a presença de mulheres depende, também, do tipo de organização.

A partir de levantamento comparativo de diversos países com democracias mais consolidadas, Norris (1996, p. 321) construiu uma tipologia que resume as quatro formas organizacionais básicas predominantes nesses países, baseadas em duas dimensões: no grau de institucionalização e no grau de centralização dos processos decisórios. No que tange à dimensão institucional, o sistema e as suas as regras podem mais ou menos formais ou informais. No que tange à centralização, o sistema pode ser mais centralizado ou mais localizado. Como tipos ideais, esses padrões são aproximações de práticas mais encontradas e não há, necessariamente, recortes nítidos e excludentes entre os quatro formatos.

Assim, quanto mais institucionalizada a dinâmica e o funcionamento orgânico das estruturas internas e dos processos de seleção partidária, quanto mais apoiado em normas e procedimentos institucionalizados e menos apoiados em relações e lideranças pessoais, seja na estruturação de seu aparato decisório, seja na prática da seleção de candidaturas, maiores as chances de que políti-

pela representação política vai orientar todo o restante de sua ação; se se trata da socialização política de maneira mais ampla, envolvendo a formação, a divulgação e a organização dos indivíduos, seu objetivo não seria apenas ou fundamentalmente a competição eleitoral. Sobre essa questão, ver, entre outros, Bourdieu (1998) e Lima Júnior (1997). 
cas favoráveis às mulheres venham a ser efetivadas dentro do partido e de que haja maior participação e controle sobre a condução de políticas e os critérios de recrutamento (GUADAGNINI, 1993; NORRIS, 1993; MATLAND, 2002). Cabe salientar que a institucionalização é referida aqui aos procedimentos internos do partido, ou seja, ao modo como as regras são estabelecidas, formalizadas e conduzidas de maneira sistemática pela estrutura partidária. Isso porque existem as regras formais, regras legais para o sistema como um todo, como é o caso das convenções partidárias no Brasil, e existem as regras internas ao próprio partido - estas são as cruciais. Segundo Norris e outros autores, nos partidos em que predominam estruturas orgânicas mais institucionalizadas, o processo de seleção de dirigentes e candidatos é orientado por regras internas mais padronizadas, que tendem a ser públicas, detalhadas, transparentes e reconhecidas pelo conjunto dos integrantes do partido (GUADAGNINI, 1993; MATLAND, 2002). Nesse caso, há duas vantagens: a possibilidade de que prováveis concorrentes ou candidatos possam estabelecer estratégias antecipadas caso queiram disputar cargos ou vagas para a competição eleitoral, assim como a vantagem de que qualquer tentativa de alteração das regras por parte de dirigentes possa vir a ser mais facilmente questionada. A institucionalização tende, assim, a ser favorável aos novos atores que queiram ingressar ou competir e, neste caso, também às mulheres. Em partidos cujas estruturas são pouco claras tornase mais difícil considerar determinadas políticas nacionais de médio ou longo prazo. Como sugeriu Matland (2002, p. 117), “[...] regras e procedimentos explícitos de nomeação podem permitir que as mulheres identifiquem os marcos-chave de decisão em tornos dos quais podem mobilizarse em prol de suas reivindicações de representação"13. Já regras pouco claras dificultam o reconhecimento do terreno e a ação coletiva de demandas ou controle sobre as direções.

De outra parte, nos partidos em que predominam a informalidade e a cultura das decisões mais personalizadas, tais processos tendem a ser relativamente fechados, passando ao largo da militância, ficando sob a responsabilidade de al-

13 As citações cujos originais são em língua estrangeira foram traduzidas pela autora. guns dirigentes. Muitas vezes os critérios são claros para os dirigentes, mas raramente são explicitados para o conjunto do partido, podendo também variar bastante de uma eleição para outra. Nesse sentido, aqueles que não estão diretamente envolvidos nos centros de decisão possuem reduzida capacidade de interferência e disputa. Muitos partidos têm em seus procedimentos informais, em suas práticas e costumes a via principal de deliberação e funcionamento e estes, em geral, caracterizam-se pela personalização das decisões. Nesses casos, o processo pode tornarse mais suscetível a práticas "personalistas" e a interesses externos aos interesses programáticos do próprio partido, o que desencorajaria o ingresso de mulheres em função da característica desordenada e personalizada da competição. A institucionalização implica também a estruturação orgânica do partido dos níveis nacional ao local, por meio de regras claras quanto ao papel e à estrutura de cada instância. Segundo Matland (2002, p. 120), do ponto de vista do recrutamento eleitoral, sistemas burocráticos baseados em regras e critérios estabelecidos previamente oferecem vantagens significativas para as mulheres, uma vez que as definições sobre cargos e eleições, em geral, consideram as estruturas organizativas de participação e, nesse sentido, haveria mais chances de as demandas das mulheres serem consideradas.

Quanto ao grau de centralização ou descentralização dos processos decisórios, é destacado que, nos sistemas centralizados, os atores decisivos são as autoridades centrais dentro do partido, categoria em que podem estar incluídos os membros das executivas nacionais ou regionais, parlamentares eleitos e ainda líderes de facções. Já nos sistemas cujas decisões são predominantemente localizadas, os atores centrais tendem a ser os representantes locais, categoria em que podem ser incluídos chefes de executivo, líderes de facções locais e membros de organizações de base, entre outros. Cabe observar aqui que, diferentemente da primeira dimensão, não há muito consenso sobre o grau em que um sistema mais centralizado ou localizado pode ser mais favorável. Enquanto alguns autores tendem a ver no sistema descentralizado, desde que formal, mais chances de setores fora da elite partidária influenciarem os processos (NORRIS, 1996; MATLAND, 2002), outros autores (GUADAGNINI, 1993) observam que a existên- 
cia de órgãos nacionais estruturados e com reconhecida direção sobre o corpo partidário, com critérios gerais a serem observados, em contraposição a partidos menos centralizados porque mais regionalizados, tenderia a ser fator importante para a movimentação interna desses setores que não compõem a elite dirigente. $\mathrm{E}$ isso tanto no sentido de superar os interesses paroquiais que tendem a predominar nas decisões mais localizadas como nas possibilidades de implantação de políticas nacionais de ação afirmativa, já que muitas vezes essas lideranças são pouco sensíveis a ações que alterem as correlações de força já estabelecidas. De outra parte, partidos com alto grau de centralização podem ser pouco maleáveis às dinâmicas regionais e aos novos atores, inclusive às mulheres.

Esses dois vetores organizacionais e as suas intercessões responderiam, assim, por quatro tipos principais de recrutamento político sistematizado por Norris (1996, p. 317):

a) o recrutamento centralizado-informal: os interesses locais tendem a fazer-se presentes nas disputas mas é a elite central que exerce considerável controle e não há regras ou critérios explícitos e claros sobre recrutamentos ou definições de cargos; as decisões tendem a darse por meio de processos de barganha entre líderes centrais das frações internas que disputam o controle; tais decisões dependeriam muito da "simpatia" dos líderes partidários e de seu poder. Como ficam as mulheres? Segundo a autora, nesse sistema de "autocracia benevolente" as mulheres podem ser promovidas com relativa facilidade, dependendo da "simpatia" das lideranças partidárias e do seu poder. Mas sem salvaguardas institucionalizadas, tais ganhos podem ser rapidamente invertidos. Um segundo fator desfavorável é que qualquer mudança depende da disposição das lideranças para alterar o status existente e, portanto, mesmo as oportunidades que surgem podem ser eventualmente bloqueadas;

b) o recrutamento informal e localizado seria mais encontrado entre os partidos nanicos. Não há regras padronizadas e, como as decisões ficam nas mãos dos representantes locais, as possibilidades de ações afirmativas ou metas de candidaturas de mulheres também seriam limitadas; seria mais difícil para as lideranças centrais jogar papel decisivo e certos atores, tais como mídia local, os financiadores individuais e lideranças locais, desempenhariam papel mais relevante. Neste caso, é difícil saber até onde os partidos podem agir para além da retórica;

c) o recrutamento formal-localizado: regras explícitas e burocráticas tendem a ser estabelecidas e implementadas nos processos decisórios e de seleção, por meio da organização nacional ou regional. De acordo com Norris, neste processo as escolhas dos indivíduos para competir são tomadas, sobretudo, no nível local, embora instâncias regionais possam desempenhar algum papel. Instâncias nacionais também podem monitorar processos e aprovar formalmente as escolhas, mas raramente decidem sobre elas. É o tipo mais comum na Europa Ocidental e

d) o recrutamento formal-centralizado: os líderes nacionais ou as executivas nacionais dos partidos teriam a autoridade constitucional para decidir quais os candidatos seriam prioritários para o partido. Esse tipo de recrutamento, segundo a autora, seria mais típico dos partidos comunistas.

Com efeito, uma vez que os partidos buscam o poder - e na sociedade contemporânea fazemno, predominantemente, por meio de eleições -, o tipo de dinâmica e organização partidárias tende a orientar um ou outro tipo de militância política e a estar intimamente ligado ao processo de recrutamento eleitoral. A partir da análise de alguns partidos, Norris (1993, p. 323) conclui que o tipo de organização em que políticas de discriminação positiva, como cotas, tenderiam a ser mais favorecidas seria o tipo formal-descentralizado. Quanto a isso, é preciso, mais uma vez, observar tratar-se de uma tipologia, construída com base na dinâmica das democracias ocidentais mais consolidadas e, portanto, passível de adequações em se tratando de democracias emergentes que estão desenhando o seu sistema partidário. De todo modo, constitui um ponto de partida útil para pensar a situação brasileira.

É mister observar que a separação analítica entre as duas dimensões não retira a sua articulação efetiva na conduta da política partidária, na engenharia eleitoral com vistas ao poder e na forma como as cotas podem ou não recortar as lógicas eleitorais. $\mathrm{O}$ mencionado trabalho de Norris e Inglehart (2003) sobre a tendência à reprodução de uma lógica inercial no recrutamento eleitoral 
ajudar-nos a articular essas duas dimensões com a lógica eleitoral para pensarmos as possibilidades das cotas nesse processo. Como foi visto, a fim de que os riscos eleitorais sejam minimizados, as escolhas dos dirigentes partidários levam em consideração quem já está comprovadamente testado eleitoralmente ou quem tem potencial para entrar na disputa. A elite política, ou quem já está testado, tem certas características mais típicas, como ser masculina, pertencer a certas profissões e ser tradicionalmente oriunda de determinados grupos étnicos ou sociais; assim, sem formas de intervenção externa, as alterações nos padrões de ingresso tendem a ocorrer nesse ritmo inercial. A adoção de medidas como cotas de candidaturas ou de assentos administrativos ou legislativos constituiriam medidas externas que quebrariam essa tendência. Por sua vez, essas adoções estariam condicionadas a um fator mais geral: o sistema e as leis eleitorais também determinam o grau de incentivo para a adoção de políticas de cotas bem como das regras que tornam efetivo o seu funcionamento.

Mais ainda: para que a escolha pragmática e racional dos dirigentes e a inércia que dela tende a resultar possam ser alteradas pelas cotas, fatores ideológicos e/ou organizacionais também necessitariam operar no processo, de modo a possibilitar equilíbrios entre compromissos ideológicos com as cotas e determinantes pragmáticos. Neste caso, a característica organizacional dos partidos pode ser decisiva para que tais medidas possam ser preservadas nas engenharias eleitorais. Fóruns decisórios não formais e mais coletivos podem funcionar como fator de pressão para a preservação de compromissos que ultrapassam o momento eleitoral.

Tendo sido analisadas as principais dimensões envolvidas no sistema partidário e em sua relação com o sistema eleitoral, a seção seguinte do artigo procura introduzir essas reflexões no caso brasileiro e articulá-las com a experiência recente da adoção de cotas.

\section{VI.O SISTEMA PARTIDÁRIO BRASILEIRO E A PARTICIPAÇÃO DAS MULHERES}

O sistema partidário brasileiro tem sido objeto de grandes debates e controvérsias, que não serão analisadas dentro do escopo deste trabalho ${ }^{14}$.

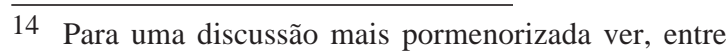

Para o momento é suficiente definir os traços gerais que o caracterizam e sobre os quais existe certa convergência para, em seguida, tentar pensar alguns reflexos sobre a participação das mulheres.

Um primeiro e mais saliente aspecto diz respeito ao alto nível de fragmentação que o caracterizou nos últimos dez anos. A partir de análises comparativas, baseadas em distintos critérios de aferição, a maior parte dos trabalhos aponta o Brasil como um país com alto nível de fragmentação partidária. Essa fragmentação seria elevada mesmo quando se consideram apenas os partidos com acesso ao parlamento, retirando-se aqueles que apenas concorrem sem alcançar quociente eleitoral suficiente para a representação parlamentar (KINZO, 1993; TAVARES, 1994; RODRIGUES, 1995; NICOLAU, 1996; LIMA JÚNIOR, 1997; TAVARES, 2002). O consenso pára aqui. O mesmo não pode ser dito quando se trata de identificar as razões para que isto ocorra e a extensão em que essa fragmentação afeta - ou não - a estabilidade da democracia. Para alguns, o multipartidarismo brasileiro é visto como extremado e, nesse sentido, como um problema que gera impactos negativos sobre a dinâmica política representativa e a relação poder Legislativo versus poder Executivo. Para outros, a fragmentação é inerente ao próprio sistema multipartidário; o número de partidos brasileiros não destoaria dos números encontrados nas democracias européias com representação proporcional (FIGUEIREDO, 2004) e, isoladamente, não constituiria problema maior para a democracia e a dinâmica política. Nesse caso, o próprio multipartidarismo extremado seria uma decorrência de outro fator a ser corrigido - a construção dos critérios de proporcionalidade - e não o elemento gerador do problema.

O personalismo que vigora no sistema partidário é um outro aspecto bastante mencionado. Algumas características do sistema eleitoral são lembradas como fatores que contribuem para a personalização, tanto do processo eleitoral em si como da vida partidária e do sistema de eleição em candidatos individuais. Além disso, há a cultura política ainda marcada por práticas clientelistas como mediação de acesso a direitos. Assim, ao

outros, Santos (1987), Lima Júnior (1992; 1997), Nicolau (1996) e Tavares (2002). 
mesmo tempo em que os partidos constituem o locus institucional por meio do qual se dá a organização da representação política da sociedade, muitas de suas práticas e normas incentivam o papel de mediação das lideranças individuais e a competição “intra”, e não entre partidos. Além de gerar a competição no interior das próprias organizações, essa característica enfraquece a dimensão coletiva das instituições e incentiva práticas de patronagem e clientelismo (LIMA JÚNIOR, 1997).

Um terceiro aspecto que merece ser destacado é o da debilidade no grau de nacionalização dos partidos, caracterizada na existência de um hiato entre as instâncias e definições nacionais e as políticas e organizações locais. Na maior parte das agremiações predominam vínculos regionais ou locais, em detrimento de uma agregação nacional pautada por objetivos programáticos, o que leva a arranjos localizados, muitas vezes descolados das orientações nacionais e voltados para a acomodação dos interesses paroquiais das elites locais.

Em decorrência desses e de outros aspectos, vários autores concluem pela marca da debilidade na maior parte dos partidos políticos brasileiros, que se caracterizam pela ausência de organicidade e pela fluidez institucional (LAMOUNIER, 1989; KINZO, 1993; LIMA JÚNIOR, 1997). Contudo, refletindo a ausência de consenso, outro autores apontam em sentido contrário. Nicolau (1996, p. 10), por exemplo, distingue entre concepção ampla e estrita de partido, a última definida por sua característica singular de competir por votos. Nessa perspectiva, considera que há uma análise pessimista quanto à existência dos partidos políticos no Brasil. Essa análise basear-se-ia em uma concepção idealizada de partido, “[...] com características substantivamente definidas (ideologia, participação, organização) e supostamente existente em outras democracias" que serviria de modelo e definiria a inexistência dos mesmos no Brasil. Nessa mesma perspectiva, Santos (1997) constatou uma elevação do grau de coesão e de disciplina partidárias, o que sugeriria a tendência ao reforço da organicidade dessas instituições no Brasil, em detrimento da prática em torno dos atores ou líderes individuais.

Como se pode notar, não existe um consenso que facilite a análise sobre os fatores determinantes da situação das mulheres. Diante desse quadro, como se pode pensar a influência do sistema partidário brasileiro sobre o acesso das mulheres à representação? Tomando-se como indicativo as observações anteriores e analisando com parcimônia, é possível mencionar três aspectos do sistema partidário que podem afetar o desempenho das mulheres. O primeiro é a fragmentação partidária. Nesse caso, há dois possíveis resultados que apontam em direções opostas. De acordo com o que foi discutido acima, pode-se dizer que o fato de, no Brasil, em geral, predominar o multipartidarismo sem grandes e poucos partidos - compreendidos como partidos que detêm acima de 30\% das cadeiras legislativas - configuraria um cenário favorável às mulheres, pois grandes e poucos partidos, como foi visto, tendem a ter postura mais conservadora em relação aos grupos outsiders da política. Por outro lado, o fato de existir um grande número de partidos muito pequenos não facilita a eleição de mulheres, embora elas possam ser absorvidas como candidatas. Os partidos elegem pouco e, nesse caso, estão envolvidos aspectos de competitividade relacionados com o tipo de capital eleitoral requerido.

A característica do personalismo, que tende a marcar a atuação de muitos partidos, conferindolhes também uma prática política individualizada e mediada pelo clientelismo, pode ser considerada como um fator que afetaria negativamente as mulheres. Práticas pouco orgânicas e pouco institucionalizadas aumentariam a dependência dos atores que tentam ingressar em relação aos chefes políticos, dificultando uma ação política mais coletiva e programática, inclusive em relação às políticas de gênero, com implicações, também, sobre a pressão política das mulheres, conforme foi visto acima.

Por último, no que tange ao aspecto da nacionalização partidária, pode-se dizer que o constatado hiato entre os objetivos programáticos no plano nacional e os objetivos contextuais localizados, produzindo uma espécie de segmentação partidária, dificulta a implantação de políticas de gênero mais sistemáticas. A ausência de uma ação coordenada com base em orientações mais amplas e menos contextuais tende a deixar as decisões ao sabor dos interesses locais dos dirigentes. Assim, mesmo quando a direção partidária compromete-se com certas proposições, o fato de não existirem vínculos mais estreitos entre os diversos níveis hierárquicos de direção dificulta que possíveis iniciativas mais gerais venham a ser 
assumidas nas instâncias mais localizadas.

\section{ALGUMAS EVIDÊNCIAS SOBRE A SITU- AÇÃO BRASILEIRA DIANTE DESSE CE- NÁRIO}

As observações seguintes são fruto da pesquisa mencionada no início deste texto sobre os partidos políticos brasileiros; elas sintetizam algumas das práticas e percepções que puderam ser observadas durante o período investigado e procuram estabelecer nexos entre traços locais e os padrões mais gerais anteriormente discutidos. $\mathrm{O}$ fio condutor desta parte da análise é o processo de incorporação das cotas pelos partidos, trabalhado a partir de entrevistas com diferentes atores partidários - dirigentes, representantes de núcleos de mulheres, parlamentares, candidatos nãoeleitos - e da análise de seus documentos básicos - regimentos, programas e cartilhas produzidas pelos movimentos de mulheres. Com base nesse processo, tentou-se esboçar um quadro mais geral acerca de como a problemática de gênero é incorporada pelos partidos e mediada de acordo com suas características ideológicas e organizacionais. De modo breve, são apresentados alguns indicadores dessas duas dimensões, procurando identificar como as novas demandas das mulheres vêm sendo acomodadas e como os partidos diferem em seu tratamento. Dado que a análise específica do processo das cotas não é o objeto deste texto, serão feitas apenas algumas considerações gerais que podem ser pensadas para além da experiência de implantação das cotas.

É importante considerar que há certas características de nossa cultura política que são marcantes para o campo da política como um todo, mas essa cultura não é estática nem condicionante; ela é alterada, fortalecida ou enfraquecida por um conjunto de fatores, dentre os quais se encontram a perspectiva ideológica das organizações e os imperativos sociais e políticos do contexto. Portanto, é possível pensar que as mudanças políticas recentes venham a ter impactos, também, sobre a cultura organizacional dos partidos brasileiros.

VII.1. Ideologia, organização e militância partidárias na prática dos atores políticos

A vida partidária fora dos momentos eleitorais pode servir a vários propósitos e refletir o tipo de dinâmica que o partido estabelece com seus integrantes. Nesse sentido, pode ser considerada, tam- bém, como importante fator de formação e de domínio das regras do jogo político. Decerto, nem todos os partidos definem de modo idêntico o que constitui a "militância" e também a "qualificação política”. O tipo de militância varia de acordo com os objetivos centrais do partido. De igual modo, o tipo de "qualificação" requerida para o exercício de um cargo partidário ou uma candidatura depende da perspectiva ideológica e da dinâmica organizacional do partido. As organizações que não possuem vida orgânica mais sistemática certamente não comporão suas direções e nem terão como requisito que o candidato tenha experiência ou militância partidária constante. Particularmente diante do sistema eleitoral brasileiro, o capital político necessário para tentar uma candidatura não passa necessariamente por critérios de militância partidária. Nesse sentido, não cabe esperar um padrão único de atuação partidária ou "qualificação" política; no entanto, mesmo os partidos nos quais predominam as práticas mais individualizadas possuem instâncias coletivas, formais ou informais nem as utilizam quando se trata de definir procedimentos políticos estratégicos.

Por meio de diferentes critérios, a instituição partidária confere a certos indivíduos aquilo que Bourdieu (1998) define como "capital delegado", obtido em decorrência de algum tipo de investimento ou dedicação à instituição. Diante das características dos partidos, em qualquer tipo de instituição, ter domínio sobre a máquina partidária constitui importante tipo de capital político, que pode eventualmente se reverter em capital eleitoral, sobretudo quando os arranjos político-eleitorais tendem a ser mais individualizados. Assim, ter algum tipo de participação e convivência interna, cujas características dependerão da dinâmica própria a cada partido, pode ser algo importante para o conhecimento das regras do jogo, um futuro domínio da máquina partidária e possível competição eleitoral.

Tais capitais e saberes, por sua vez, encontram-se articulados às características sistêmicas e institucionais dos partidos, notadamente as ideológicas e organizacionais, discutidas em seções anteriores. Tomando como referência mais geral as duas principais dimensões envolvendo os partidos políticos, procurou-se considerar um conjunto de variáveis que pudessem oferecer indicadores sobre a variável "gênero" face às ideologias e dinâmicas organizacionais partidárias. Embora o propósito não fosse "enquadrar" os partidos 
brasileiros na tipologia discutida anteriormente, inclusive porque o universo investigado foi bastante delimitado - seis partidos políticos - e as características do nosso sistema não são exatamente as mesmas das democracias ocidentais mais consolidadas, foi possível identificar no espectro analisado contornos partidários próximos de alguns dos tipos mencionados por Norris (1996). Embora um trabalho mais criterioso de análise seja necessário, de modo bastante geral e não-conclusivo, é possível indicar certas aproximações entre os partidos analisados e a tipologia descrita. Assim, por exemplo, as dinâmicas do Partido Progressista (PP), Partido da Frente Liberal (PFL) e do Partido do Movimento Democrático Brasileiro (PMDB) surgem como mais próximas à do tipo centralizado-informal, ao passo que o Partido dos Trabalhadores (PT) parece aproximar-se mais do tipo descentralizado-formal; o Partido Democrático Trabalhista (PDT) transitaria entre o tipo centralizado-formal e descentralizado-formal, com maior proximidade do primeiro tipo ${ }^{15}$. De certo modo, se tomarmos essa referência e considerarmos os partidos por seus contingentes de mulheres nas representações internas e externas, é possível notar certa coerência com as correlações identificadas para as democracias ocidentais consolidadas.

Considerando essas perspectivas e dinâmicas, a pesquisa empírica procurou identificar qual o nível de participação dos entrevistados e como eles encontram-se inseridos nas práticas partidárias de seus respectivos partidos. Os parlamentares constituem um caso à parte, já que sua própria condição gera um tipo de relação particular. Em relação ao tempo e às motivações da filiação, constatou-se que um número maior do que o esperado de entrevistados não incluídos como dirigentes ou parlamentares tinha uma história mais longa nos seus respectivos partidos, o que sugere algum vínculo ideológico e não apenas eleitoral. Contudo, o que mais chamou atenção foi o fato de que, entre os que possuem filiação recente, a maioria era composta de mulheres e uma parte declarou que suas filiações tiveram por objetivo

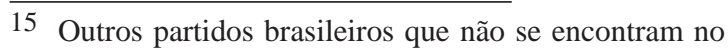
espectro analisado também podem ser aproximados, tais como o Partido Verde (PV), cujas dinâmica e características parecem mais típicos do tipo descentralizado e informal, enquanto o Partido Comunista do Brasil (PCdoB) estria mais para o tipo centralizado-formal. básico concorrer às eleições. Enquanto uma parte - sobretudo dos partidos de esquerda e algumas dos de centro - afirmava um discurso ideológico, outras salientaram que na opção pela filiação ao partido havia considerado a facilidade de contatos políticos visando a conseguir legenda para concorrer ou que poderia ter ocorrido em outros partidos com perfis semelhantes, desde que essas chances se apresentassem. Algumas candidatas, cujas filiações foram recentes, disseram-se motivadas pelas cotas. O projeto de candidatura fazia parte dos planos da maior parte das candidatas, independentemente das cotas, mas mesmo as que já pretendiam concorrer afirmaram sentirem-se mais estimuladas pela existência da lei.

Entre os entrevistados observou-se que, proporcionalmente, os homens têm uma história de envolvimento partidário mais antiga. Essa trajetória de militância mais longa resulta em maior inserção nas instâncias diretivas do partido, o que, no entanto, não é algo particular a esse universo, refletindo os padrões de inserção por gênero. Contudo, no caso das mulheres, em se tratando do universo analisado, parece haver uma interseção entre possibilidade de militância mais orgânica e perfil ideológico do partido. Em geral, mesmo considerando as mulheres cuja motivação inicial foi a candidatura, isto não parece reduzir o interesse e as expectativas quanto a uma participação mais efetiva nos partidos. A maioria dos entrevistados, homens e mulheres incluídos na categoria de não-eleitos, fez observações críticas à vida partidária, as quais foram interpretadas como certa sensação de exterioridade em relação ao que se passa no interior do partido, pela ausência de canais de expressão, sobretudo no momento eleitoral. Mas essas pessoas remetiam tais críticas, também, à ausência do funcionamento formal das instâncias. A exceção eram aqueles que compunham diretórios regionais ou instâncias importantes do partido, que se percebiam bastante afinados com as decisões e a dinâmica partidária. No entanto, nesse cenário mais uma vez os elementos ideológicos e organizacionais cruzam-se para caracterizar certas práticas. Práticas mais institucionalizadas e coletivas parecem ser comuns entre os partidos mais à esquerda, eventualmente no centro e menos comuns entre os partidos de direita. Os filiados ao PT, PDT e ao Partido da Social-Democracia Brasileira (PSDB) afirmaram ter algum tipo de militância nos seus respectivos partidos, se não por meio de participação em diretórios zonais e/ 
ou núcleos partidários, pelo menos via reuniões eventuais com os militantes da área. O outro extremo encontrava-se entre candidatas dos partidos definidos como ideologicamente de direita: a maioria disse nunca ter sido chamada para participar de qualquer reunião fora do momento eleitoral, antes ou após o pleito.

Essa condição de exterioridade é também marcada pelo gênero, pois as mulheres ressentem-se mais do que os homens, mesmo quando se comparam os atores pertencentes a um mesmo agregado ideológico. Para além do fato de possuírem militância mais recente, é provável que o envolvimento das mulheres seja condicionado por sua dinâmica de vida familiar e profissional, o que dificulta sua inserção em espaços já consolidados em suas práticas e ocupados por outros atores. Essa última observação deixa uma interrogação sobre um outro impacto das práticas mais orgânicas e perenes, ou seja, se tais práticas, que envolvem a formação de um capital político, não surtiriam um efeito contrário para as mulheres, já que elas ver-se-iam limitadas por suas atribuições domésticas e familiares. Na medida em que necessitariam dar conta de sua presença em várias dimensões simultaneamente (a política, a profissional e a doméstica) e que as carreiras internas não apenas no interior da estrutura partidária, mas na interseção com outras bases sociais - tendem a ser importantes para a disputa eleitoral, as mulheres poderiam ver-se em situações de desvantagem política. Nesse caso, a prática orgânica mais intensa poderia exercer um efeito contrário ao esperado pela literatura, evidenciando situações de desvantagem em contextos mais e menos orgânicos. Essa hipótese, porém, precisaria ser mais bem investigada.

Por fim, em relação aos parlamentares, há um certo padrão de atuação partidária que surge da observação. A participação do parlamentar dá-se, em geral, por meio de diretórios municipais e/ou regionais, porém de modo esporádico. Em geral, a dinâmica parlamentar é condicionada pela relação com suas bases eleitorais e não passa muito pelos organismos partidários, a não ser em situações especiais e momentos-chave da vida partidária. Quanto a isso, não se observaram diferenças entre os sexos. O corte um pouco mais evidente é o ideológico. Em relação às cotas, os parlamentares dos partidos de esquerda referem-se mais constantemente a algumas discussões ocorridas nos diretórios, dominavam mais o tema das cotas e demonstraram ter maior conhecimento acerca da dinâmica e das políticas partidárias do que outros tipos de militantes e até mesmo de dirigentes, sugerindo que ter um mandato pode ser bem mais relevante do que ter uma prática mais constante no partido.

\section{VII.2. Investimentos em políticas de gênero}

Investimentos em políticas de gênero podem ser entendidas como políticas ou estratégias específicas definidas oficialmente pelo partido como medidas que visam a facilitar a presença das mulheres na vida partidária, bem como iniciativas esporádicas ou permanentes em termos de formação e capacitação da militância feminina. De fato, formulações programáticas genéricas de compromisso com os direitos das mulheres são comuns a todos os partidos e por isso não constituem indicadores relevantes, a não ser para cotejar as diferentes estratégias identificadas por Lovenduski (1993) e Norris (2003). Mas aqui é interessante mencionar que os registros relacionados às mulheres nos programas partidários de alguns desses partidos ainda surgem tendo como forte referência à sua condição de mãe e instrumento de sustentação e reprodução de valores familiares e não à sua condição de sujeitos políticos configurados independentemente da maternidade e/ou da família ${ }^{16}$.

Acompanhando a tendência geral mencionada anteriormente, também no Brasil os partidos começam a adotar cotas para as suas instâncias partidárias. Essa política ainda é mais presente entre os partidos definidos como de esquerda e menos entre os definidos como de direita. No caso dos partidos analisados, o PT apresenta uma trajetória mais sólida na adoção dessa política, embora isso não signifique ausência de conflitos. Além disso, até o momento da coleta dos dados - março de 2003 -, integrantes da secretaria de mulheres do PT e do PSDB mencionaram iniciativas na área de formação, com cursos sobre relações de gênero integrando a agenda dos órgãos responsáveis pela formação. A publicação de materiais dirigidos às mulheres também começa a ser uma prática partidária comum, especialmente em períodos próximos às eleições. Um exemplo recente é a publicação do Partido da Frente Liberal (PFL), no

16 Esses são os casos, por exemplo, dos programas nacionais do PPB/PP, ambos editados em 1999. 
ano de 2001 (PFL, 2001). Constatou-se, também no PT, certo tipo de apoio mais logístico, que pode envolver a prestação de serviços de creches quando ocorrem eventos maiores, como, por exemplo, congressos e encontros. Mas todas essas iniciativas foram demandas dos núcleos de mulheres, envolvendo muitas negociações e conflitos internos.

\section{VII.3. Presença nas instâncias deliberativas}

Decerto, as cotas podem ser importantes para que questões venham a ser incorporadas na agenda dos partidos. O grau de inserção nas instâncias decisórias pode expressar também as políticas e os espaços que os partidos conferem às mulheres, além de ser indicador do estado geral da sua participação partidária. Como foi mencionado, esse não é um problema particular ao Brasil, afetando, de maneira significativa, partidos com diferentes perfis ideológicos, inseridos em diferentes sistemas políticos, conforme foi mostrado anteriormente. Em levantamento realizado em 1997, envolvendo 418 partidos de 86 países em diferentes continentes, constatou-se que em apenas 10,8\% desses partidos as mulheres ocupavam cargos de presidente ou secretária-geral (IPU, 1997). Exatamente por isso, a extensão em que as mulheres encontram-se inseridas nas instâncias decisórias pode dizer-nos muito sobre a cultura política predominante em relação ao gênero e o compromisso e o investimento do partido em prol de melhor equilíbrio na participação. Por outro lado, as políticas de cotas, sozinhas, parecem ter pequeno poder de alterar as regras do jogo partidário. A presença das mulheres pode ou não expressar mudanças efetivas no sistema de valores e de práticas dos partidos. Nesse sentido, embora as metas de inclusão nas instâncias decisórias sejam importantes, sem alterações que permitam que essas próprias instâncias tenham, de fato, poder de decisão e sem mecanismos institucionais que possibilitem às mulheres sair da condição de exterioridade à dinâmica partidária, a presença nos diretórios pode ser apenas formal.

Neste texto não serão apresentados dados estatísticos sobre a participação de mulheres em diretórios, mas cabe adiantar que essa participação tem crescido em geral nos últimos dez anos. Contudo, a clivagem ideológica é clara. Os partidos de esquerda apresentam números bem mais significativos que os de centro e de direita e os partidos de centro apresentam índices mais ele- vados que os de direita. Quando nos voltamos para examinar os órgãos executivos, aqueles que representam o núcleo de poder e que realmente decidem a vida partidária, os percentuais de participação sofrem alguma variação, mas mantêm-se mais significativos entre os partidos de esquerda. A comparação entre partidos que possuem políticas de gênero, voltadas para a participação nas instâncias decisórias, e partidos que não possuem, sugere que há alguma eficácia dessas políticas, alargando a presença feminina nos centros de decisão.

\section{VII.4. A organização das militantes partidárias}

Tradicionalmente, foram os partidos alinhados à esquerda aqueles que mais tomaram iniciativas no sentido de estimular a organização específica das mulheres. Contudo, há indícios cada vez mais fortes de que tais iniciativas vão perdendo essa conotação ideológica e começam a perpassar as organizações partidárias em geral. Por um lado, essas inclusões refletem a legitimidade e o espaço que o tema da participação política da mulher adquiriu na sociedade. Por outro, como consequiência dessa legitimidade, refletem também a percepção partidária de que as mulheres e/ou o tema dos direitos das mulheres ganhou apelo eleitoral e, portanto, é proveitoso incorporá-lo de alguma forma. Nesse sentido, ter previsto em seu estatuto a "organização das mulheres", assim como de outros "setores específicos", não constitui mais um indicador significativo de compromissos com a questão de gênero, mas o reconhecimento geral que o tema da inclusão de certos setores sociais adquiriu no campo da política. De todo modo, isso pode ser considerado um tipo de "efeito contágio", de determinados partidos sobre outros, decorrente da pressão e organização das mulheres.

Possuir ou não uma organização de mulheres no partido pode fazer diferença, quer seja na capacidade de, em nome do partido, tomar iniciativas de apoio e mobilização das candidatas, quer seja na atuação como instrumento de pressão política sobre as direções partidárias ou ainda como instrumento de mobilização de mulheres para as campanhas majoritárias do partido. Contudo, vale considerar dois aspectos. Um primeiro é que este não é um dado independente de outras variáveis. O grau de organização desses movimentos ajuda a definir seu nível de influência junto às direções partidárias. Um segundo é que, mesmo entre os partidos com tradição de organização, o poder de 
mobilização e, sobretudo, de pressão junto às direções partidárias é muito escasso; as ações, como se viu, assumem uma característica mais ou menos paralela ao núcleo de articulação e ação política dos partidos, sem muito poder de influência sobre as decisões partidárias centrais.

\section{EM QUE OS PARTIDOS FAZEM DIFE- RENÇA?}

Em seu robusto estudo comparativo sobre a organização partidária, Katz e Mair (1992, p. 1) afirmam que os partidos importam e "permanecem como a forma básica, representativa e legítima de ligação entre cidadãos e o Estado". Caminhando em sentido oposto a boa parte dos estudos recentes, que destacam o esgotamento dessas agremiações como veículo de organização coletiva e canal de viabilização da representação política, os autores afirmam que os partidos continuam a ser o principal meio por meio do qual a população pode cobrar de seus governantes suas responsabilidades e seus desempenhos nos cargos. Afirmam, também, que não há evidências empíricas de que a era dos partidos tenha passado e concluem que essas organizações permanecem centrais para as concepções modernas de processo democrático. Entretanto, reconhecem que há aspectos centrais que podem indicar o grau em que os partidos conseguem organizar-se para responder aos conflitos sociais, comprometer-se com demandas e incluir novas configurações sociais geradas pela sociedade. Além disso, enumeram uma série de fatores relevantes que dão margem às críticas dirigidas aos partidos. Entre esses fatores, os autores incluem a organização, as políticas e a presença de mulheres em suas direções internas e em seus cargos legislativos (idem). Os dados da pesquisa, que cobriu até o ano de 1990, mostraram que, na época, a maior parte das organizações não possuía políticas muito claras de organização de mulheres, mas entre as que possuíam podia ser identificado um perfil ideológico mais à esquerda e/ou partidos menos tradicionais. Já as informações mais recentes (IPU, 2000; DALRHUP, 2003; NORRIS, 2003) sugerem uma alteração positiva nesse quadro. Ou seja, muitos partidos têm explicitado em seus programas compromissos com a igualdade e têm também criado políticas de ação afirmativa e políticas de cotas para seus cargos internos e externos.

No cenário brasileiro, os partidos em geral vêm respondendo aquém das expectativas em relação ao processo interno que envolve a adoção das cotas. As cotas constituem hoje um dos principais emblemas de compromissos partidários para com as mulheres. Nesse sentido, pensando as organizações partidárias com base em um continuum que vai da esquerda à direita, pode-se concluir por uma debilidade menor entre os partidos de esquerda e maior debilidade entre os de direita. Contudo, se os partidos diferenciam-se de algum modo na forma como seus dirigentes percebem a política de cotas e na condução inicial dada ao processo, essa diferenciação parece dissipar-se no que tange à competição eleitoral. Os investimentos, assim como as lógicas que comandam as estratégias de competição, obedecem predominantemente aos imperativos eleitorais e, nesse sentido, desconhecem, ao mesmo tempo em que reproduzem, possíveis desigualdades de gênero como variável interveniente entre os competidores. Quanto a isso, os partidos aproximam-se na forma da argumentação: o partido tem que preservar a sua estratégia eleitoral e, sobre isso, não há muito como definir políticas específicas.

Cabe perguntar, por fim: como as características ideológicas e organizacionais dos partidos afetam as estratégias das mulheres? No Brasil, os partidos incorporam um discurso favorável à mulher em seus programas, plataformas eleitorais e nos pronunciamentos dos dirigentes. Isso pode ser visto como algo positivo, na medida em que expressa o apoio e o apelo que o tema dos direitos das mulheres angariou na sociedade como um todo. Mas para além dos compromissos intencionais, poucos são os partidos brasileiros que implementam ações mais substantivas nesse sentido. Resgatando os três tipos de estratégias elaborados por Lovenduski (1993) e Norris (2003), pode-se dizer que em termos de compromissos ideológicos e mudanças organizacionais a estratégia da retórica ainda é predominante entre os partidos brasileiros analisados e a adoção das cotas não foi, até o momento, suficiente para alterar esse cenário; a análise com base na clivagem ideológica e no grau de institucionalização partidária confirma que há uma variação na forma como os partidos respondem internamente às demandas das mulheres, sendo tal resposta mais efetiva à medida que os partidos encontram-se mais à esquerda e são mais estruturados organicamente. Ao mesmo tempo, é possível indicar, para futuras investigações, que há alguma proximidade entre os modelos de organização partidária discutidos e as 
práticas mais ou menos favoráveis às políticas de gênero no interior dos partidos brasileiros. Mas, em geral, pode-se dizer que a permanência de uma cultura política ainda pouco marcada por valores igualitários em relação ao gênero dificulta a ampliação de investimentos partidários nessas políticas, as quais, em certas circunstâncias, exigem lógicas menos localistas e mais ideológicas.

Vale notar que a pressão e a capacidade de organização das mulheres são aspectos que influenciam na capacidade de resposta do partido. Contudo, quando se passa do plano da participação interna para o da representação eleitoral, percebese que o nível de diferenciação entre os partidos decresce bastante. Embora possam-se observar certas diferenças no quadro do recrutamento eleitoral das candidaturas - em termos de quem entra por onde - os tipos de investimentos de gênero não necessariamente se revertem em capital eleitoral. Quanto a isso, parecem pertinentes as conclusões de Samuels (1997, p. 525), quando sugere que " $[\ldots]$ em importantes aspectos da estratégia eleitoral, no Brasil a ideologia pode ser derrotada pelas regras eleitorais”.

Com efeito, se as políticas de cotas contam e podem contribuir para ampliar a presença das mulheres nos partidos, quando se trata do momento da eleição, no caso brasileiro, essa contribuição tende a ficar condicionada à lógica do sistema eleitoral, bem como aos arranjos políticos oriundos dessa lógica. Diferenças ideológicas podem estabelecer certos padrões de ação e de compromisso para os partidos; a cultura política estabelece de maneira mais ou menos intensa determinadas características organizacionais e os valores de gênero também se exprimem em consonância com os valores culturais e os perfis eleitorais dos partidos. Mas, ao lado disso, há dimensões institucionais e a conexão entre o sistema partidário e o sistema eleitoral, envolvendo, entre outros, o tipo de lista, contam e influenciam o formato e as práticas partidárias, inclusive em relação ao processo de recrutamento eleitoral e à lógica que comanda os investimentos eleitorais. Como foi mencionado, o recrutamento partidário com vistas à competição eleitoral, isto é, a construção e definição de candidaturas, são mediadas por padrões e perfis eleitorais já testados e/ou com capital eleitoral capazes de estar efetivamente na competição. As cotas podem incidir sobre essa dinâmica, mas podem ser também limitadas por ela. No caso brasileiro, devido à característica do sistema de lista aberta e a individualização da competição, é provável que essa tendência inercial opere de modo desfavorável às mulheres no momento de distribuição de apoio e/ou investimentos partidários. As cotas parecem ser limitadas para alterar essa lógica. Isso, contudo, não significa estabelecer uma contraposição entre sistemas de lista (aberta ou fechada) e situações favoráveis ou desfavoráveis às mulheres. Muitas análises, envolvendo sistemas que adotam listas fechadas, têm mostrado que as mulheres ficam dependentes dos dirigentes partidários no momento de definir sobre aqueles que serão elegíveis, isto é, que encabeçarão as listas. A forma como as cotas têm sido incorporadas e efetivadas nesses sistemas também depende do comprometimento dos partidos com essas medidas, da pressão organizada das mulheres e da sua capacidade de interferir na construção das políticas de recrutamento e investimento eleitoral. Em suma, o desenho dos partidos, a capacidade de as mulheres inserirem-se em suas dinâmicas políticas e organizacionais e sua força como grupo de pressão interna podem fazer diferença na definição das prioridades eleitorais. Contudo, qualquer que seja o tipo de intervenção, é necessário considerar o grau em que a variável "gênero" influencia ou é influenciada por essa característica multifacetada da política e quais desenhos institucionais da política tendem a ser mais democráticos e a garantir critérios mais justos de representação.

Clara Araújo (cmaraujo@superig.com.br)é Doutora em Sociologia pela Universidade Federal do Rio de Janeiro (UFRJ), Professora do Departamento e da Pós-graduação de Ciências Sociais da Universidade do Estado do Rio de Janeiro (UERJ) e Coordenadora da Linha de Pesquisa Justiça e Desigualdade nas Práticas Sócio-Políticas da UERJ. 


\section{REFERÊNCIAS BIBLIOGRÁFICAS}

ARAÚJO, C. 1999. Cidadania incompleta : o impacto da lei de cotas sobre a representação política das mulheres brasileiras. Rio de Janeiro. Tese (Doutorado em Sociologia). Universidade Federal do Rio de Janeiro.

2001. As cotas por sexo para a competição legislativa : o caso brasileiro em comparação com experiências internacionais. Dados, Rio de Janeiro, v. 44, n. 1, p. 155-195.

BOTTOMORE, T. 1979. Sociologia Política. Rio de Janeiro : Zahar.

BOURDIEU, P. 1998. O poder simbólico. $2^{\mathrm{a}}$ ed. Rio de Janeiro : B. Brasil.

CHAPMAN, J. 1993. Politics, Feminism and Reformation of Gender. London : Routledge.

DALRHUP, D. 2003. Comparative Studies of Electoral Gender Quotas. In : International IDEA (ed.). The Implementation of Quotas : Latin American Experiences. Quota Workhop Report Series, n. 2. Stockholm : International Institute for Democracy and Electoral Assistance.

DARCY, R.; WELCH, S. \& CLARCK, J. 1994 Women, Elections and Representation. Lincoln : University of Nebraska.

DIAZ, M. M. 2002. Are Women in Parliament Representing Women? Louvain : Université Catholique de Louvain.

ERICKSON, L. 1993. Making Her Way. Women, Parties and Candidacies in Canada. In : LOVENDUSKI, J. \& NORRIS, P. (eds.). Gender and Party Politics. Londres : Sage.

FIGUEIREDO, M. 2004. Participação política. Brasil em números. Rio de Janeiro : Instituto Brasileiro de Geografia e Estatística.

GALLIGAN, I. 1993. Party Politics and Gender in the Republic of Ireland. In : LOVENDUSKI, J. \& NORRIS, P. (eds.). Gender and Party Politics. Londres : Sage.

GUADAGNINI, M. 1993. A “Partitocrazia” without Women : The Case of Italian Party System. In : LOVENDUSKI, J. \& NORRIS, P. (eds.). Gender and Party Politics. Londres : Sage.

HTUN, M. \& JONES, M. 2002. Engendering the Right to Participate in Decision-Making :
Electoral Gender and Women's Leadership in Latin America. In : CRASKE, N. \& MOLYNEUX, M. (eds). Gender and the Politics of Rights and Democracy in Latin America. New York : Palgrave.

HTUN, M. 2002. Mujeres y poder político en Latinoamérica. In : MENDEZ-MONTALVO, M. \& BALLINGTON, J. (orgs.). Mujeres en el Parlamento. Mas allá de los números. Stockholm : Institute for Democracy and Electoral Assistance.

IDEA. 2003. Global Database of Quotas for Women. Stockholm : Institute for Democracy and Electoral Assistance. Disponível em : http://www.quotaproject.org/. Acesso em : 23.maio.2003.

IPU. 1997. Men and Women in Politics : Democracy Still in the Making. A Comparative Study. Report and Documents n. 28. Geneve : Inter-Parliamentary Union.

2000. Women in Politics - 1945-2000. Reports and Documents n. 37. Geneve : InterParliamentary Union.

KATZ, R. \& MAIR, P. 1992. Party Organizations. Londres : Sage.

KINZO, M. D. 1993 Radiografia do quadro partidário brasileiro. São Paulo : Fundação Konrad Adenauer.

LAMOUNIER, B. 1989. Partidos e utopias : o Brasil no limiar dos anos 90. São Paulo : Loyola.

LIMA JÚNIOR, O. B. 1992. Reforma institucional e aperfeiçoamento dos sistema eleitoral e partidário. Agenda de Políticas Públicas n. 2. Rio de Janeiro : IUPERJ.

1997. Instituições políticas democráticas. Rio de Janeiro : J. Zahar.

LOVENDUSKI, J. 1993. The Dynamics of Gender and Party Politics. In : LOVENDUSKI, J. \& NORRIS, P. (eds.). Gender and Party Politics. London : Sage.

1996. Sex, Gender and British Politics. In : LOVENDUSKI, J. \& NORRIS, P. (eds.). Women and Politics. Oxford: Oxford University.

MATLAND, R. \& STUDLAR, D. 1996. The Contagion of Women Candidates in Single- 
Member District and Proportional Representation Electoral Systems : Canada and Norway. The Journal of Politics, Nashville, v. 58, n. 3, p. 707-733, Aug.

MATLAND, R. 2002. Estrategias para ampliar la participación femenina en el parlamento. El proceso de selección de candidatos legislativos y los sistemas electorales. In : MENDEZMONTALVO, M. \& BALLINGTON, J. (orgs). Mujeres en el Parlamento - más allá de los números. Stockholm : Institute for Democracy and Electoral Assistance.

MENDEZ-MONTALVO, M. \& BALLINGTON, J. (orgs.). 2002. Mujeres en el Parlamento. Mas allá de los números. Stockholm : Institute for Democracy and Electoral Assistance.

NICOLAU, J. 1996. Multipartidarismo e democracia. Rio de Janeiro : Fundação Getúlio Vargas.

NOHLEN, D. 1995. Sistemas electorales y partidos políticos. $2^{\mathrm{a}}$ ed. Ciudad de México : Fondo de Cultura Económica.

NORRIS, P. \& INGLEHART, R. 1996 Women Politicians : Transforming Westminster? In : NORRIS, P. \& LOVENDUSKI, P. (eds.). Women in Politics. Oxford : Oxford University.

2000. The Development Theory of the Gender Generation Gap : Women's and Men's Behavior in Global Perspective. International Political Science Review, London, v. 21, n. 4, p. 441-163.

2003. Gender Equality and Cultural Change around the World. Cambridge, Mass. : Cambridge University. Disponível em : http:// www.pippanorris.com. Acesso em : 25.abr.2003

NORRIS, P. \& LOVENDUSKI, J. 1993. Conclusion. In : Party Politics. London : Sage.

NORRIS, P. \& LOVENDUSKI, J. 1995. Political Recruitment : Gender, Race and Class in the British Parliament. Cambridge, Mass. : Cambridge University.

NORRIS, P. 1993. Comparing Legislative Recruitment. In : NORRIS, P. \& LOVENDUSKI, P. (eds.). Gender and Party Politics. London : Sage.
1999. Gender : A Gender Generation Gap? In : EVANS, G. \& NORRIS, P. (eds.). Critical Elections - British Parties and Voters in LongTerm Perspective. London : Sage.

2003. Electoral Enginering : Voting Rules and Political Behavior. Preliminary version. Disponível em : http://www.pippanorris.com. Acesso em : 25.abr.2003.

PFL. 2001. Cartilha da mulher. Brasília : Partido da Frente Liberal.

RODRIGUES, L. M. 1995. As eleições de 1994 : uma apreciação política. Dados, Rio de Janeiro, v. 38, n. 1, p. 71-92.

RULE, W. \& ZIMMERMAN, J. (eds.). 1994. Electoral Systems in Comparative Perspective : Their Impact on Women and Minorities. Westport : Greenwood.

RULE, W. 1994. Parliament of, by, and for the People : Except for Women? In : RULE, W. \& ZIMMERMAN, J. (eds.). Electoral Systems in Comparative Perspective : Their Impact on Women and Minorities. Westport : Greenwood.

1997. Political Rights, Electoral Systems and the Legislative Representation of Women in 73 Democracies : A Preliminary Analysis. Paper presented at the XVII World Congresso of International of Political Science Association, occurred at Seoul, in August. Digit.

SAINSBURY, D. 1993. The Politics of Increased Women's Representation : the Swedish Case. In : NORRIS, P. \& LOVENDUSKI, J. (eds.). Gender and Party Politics. London : Sage.

SAMUELS, D. 1997. Determinantes do voto partidário em sistemas eleitorais centrados no candidato : evidências sobre o Brasil. Dados, Rio de Janeiro, v. 40, n. 3, p. 493-536.

SANTOS, F. 1997. Patronagem e poder de agenda na política brasileira. Dados, Rio de Janeiro, v. 40, n. 3, p. 465-492.

SCHMIDT, G. 2003. Cuotas efectivas, magnitud relativa del partido, y el éxito de las candidatas mujeres : una evaluación comparativa de las elecciones municipales peruanas. Lima : Movimiento Manuela Ramos.

SHORT, C. 1996. Women and the Labour Party. In : LOVENDUSKI, J. \& NORRIS, P. (eds.). 
Women and Politics. Oxford : Oxford University.

SKJEIE, H. 1996. Engendering the Male Political Hegemony : The Norwegian Experience. In : NORRIS, P. \& LOVENDUSKI, J. (eds.). Gender and Party Politics. London : Sage.

TAVARES, J. G. 1994. Sistemas eleitorais nas democracias contemporâneas. Teoria, instituições, estratégias. Rio de Janeiro : Relume Dumará.

2002. Sistemas eleitorais e federação no Brasil : as lições da Alemanha. Texto apresentado na Conferência Internacional "Reforma política no Brasil em perspectiva comparada”, realizado em junho de 2002, no Rio de Janeiro. Digit.

VIEGAS, J. M. \& FARIA, S. 2001. As mulheres na política. Oeiras : Celta.

WOODWARD, A. 2002. Going for Gender Balance. Strasbourg : Council of Europe.

ZIMMERMAN, J. 1994. Equity in Representation for Women and Minorities. In : RULE, W. \& ZIMMERMAN, J. (eds.). Electoral Systems in Comparative Perspective : Their Impact on Women and Minorities. Westport: Greenwood. 
Versão dos resumos para o inglês: Miriam Adelman

POLITICAL PARTIES AND GENDER: MEDIATIONS IN WOMEN'S ACCESS ROUTES TO POLITICAL PARTICIPATION

\section{Clara Araújo}

This article discusses the relationship between women's chances for access to political representation, in particular legislative representation, and their forms of participation in political parties. First, we look at types of representation and the party system, as dimensions of the political and electoral system. This is followed by an analysis of the political party system focusing on its organizational and ideological aspects. Based on the analysis of the literature that deals with our topic, we attempt to reflect on some of the institutional factors that within these systems have a negative or positive effect on women's chances to compete for electoral offices and be elected through political parties. This is followed by a second moment in which recent experiences of proportional quotas for the representation of both sexes have been implemented. Through research on the Brazilian case, we attempt to observe how the characteristics of the party system and the conditioning factors that we have discussed can affect the outcome of quota policies. Our conclusions show that women's access to political representation is conditioned by a complex of factors that go beyond the engineering of the political system, although efforts at engineering have an impact and can favor women's entrance into politics to a greater or lesser extent. As research has show, this influence can operate as well over the possibility that the quota system be implemented either more bureaucratically or more effectively by Brazilian political parties.

KEYWORDS: gender; political parties; institutional engineering; gender quotas. 
Versão dos resumos para o francês: Maria Fernanda Araújo Lisboa

PARTIS POLITIQUES ET GENRE : MÉDIATION SUR LES VOIES D’ACCÈS DES FEMMES À LA REPRÉSENTATION POLITIQUE

Clara Araújo

Cet article discute la relation entre les opportunités d'accès à la représentation politique pour les femmes, principalement à la représentation législative, et les formes de leur insertion dans les partis politiques. Dans un premier moment, les types de représentation et le système de partis sont considérés comme des dimensions du système politique et électoral. Ensuite, le système de partis politiques est mieux analysé en ce qui concerne leur organisation et idéologie. En s’appuyant sur la littérature abordant ce thème, on réfléchit sur quelques contraintes institutionnelles de ces systèmes et qui interviennent positivement ou négativement dans les chances pour les femmes de disputer et d'être choisies par l'intermédiaire des partis. Dans un second moment, les expériences récentes d'adoption de quotas selon le sexe pour les candidatures proportionnelles sont examinées. A partir de l'étude du cas brésilien, on cherche à observer comment les caractéristiques du système de partis et les constraintes présentées puissent influencer les résultats des quotas. Les conclusions soulignent que pour les femmes l'accès à la représentation politique subit l'influence d'un ensemble de facteurs surpassant la dynamique du système politique. Cela est important et favorise assez bien l'accès à la vie politique. Comme la recherche suggère, cette influence peut agir aussi sur la possibilité de faire en sorte que ces quotas soient envisagés plus bureaucratiquement ou bien plus efficacement par les partis brésiliens.

MOTS-CLÉS : genres; partis politiques; génie institutionnel; quotas de genre. 